\title{
PENGARUH PERSEPSI ATAS GAYA BELAJAR DAN PENGUASAAN KOSAKATA TERHADAP PEMAHAMAN BACAAN TEKS RECOUNT
}

\author{
Rizki Fitriani ${ }^{1}$ \\ Mamik Suendarti ${ }^{2}$ \\ Fakultas Pascasarjana Pendidikan Bahasa Inggris \\ Universitas Indraprasta PGRI, Jakarta \\ email: rizkifitriani0905@gmail.com ${ }^{1}$ \\ email: mamik.suendarti@unindra.ac.id ${ }^{2}$
}

\begin{abstract}
Abstrak: Penelitian bertujuan untuk menganalisis dan menguji kebenaran hipotesis mengenai pengaruh persepsi atas Gaya Belajar dan Penguasaan Kosakata terhadap Pemahaman Teks Recount. Hipotesis penelitian yang diuji meliputi: 1) Pengaruh model Gaya Belajar terhadap Pemahaman Bacaan Teks Recount. 2) Pengaruh Penguasaan Kosakata terhadap Pemahaman Bacaan Teks Recount.3) Pengaruh Gaya Belajar dan Penguasaan Kosakata terhadap Pemahaman Bacaan Teks Recount. Penelitian dilakukan dengan metode survei. Populasi adalah siswa kelas X SMA Negeri di Jakarta Selatan dengan besar sampel sebanyak 72 siswa, dengan teknik sampling yang digunakan yaitu random sampling. Instrumen penelitian yang digunakan yaitu tes butir soal Pemahaman Bahasa Inggris sebanyak 30 pertanyaan yang telah diuji homogenitasnya dengan besar Sig. = 0,00. Analisis data menggunakan analysis of varians (ANOVA) dua jalur/arah. Hasil pengujian hipotesis diperoleh kesimpulan sebagai berikut: 1) Terdapat pengaruh yang signifikan persepsi atas gaya belajar terhadap pemahaman Bacaan Teks Recount, hal tersebut dibuktikan dengan Sig. $=0.005$ dan $\left.F_{h}=15.907 .2\right)$ Terdapat pengaruh yang signifikan penguasaan kosakata terhadap pemahaman bacaan teks recount siswa SMA Negeri di Jakarta Selatan, hal tersebut dibuktikan dengan Sig. $=0.025$ dan $F_{h}=9.122$. 3) Terdapat Pengaruh yang signifikan Persepsi atas Gaya Belajar dan Penguasaan Kosakata terhadap pemahaman Bacaan Teks Recount siswa SMA Negeri di Jakarta Selatan, hal tersebut dibuktikan dengan Sig. $=0.000$ dan $F_{h} 10.358$. Hasil penelitian ini berguna untuk meningkatkan kualitas pembelajaran dan meningkatkan pemahaman Bacaan Teks Recount di tingkat SMA.
\end{abstract}

Kata Kunci : persepsi atas gaya belajar; penguasaan kosakata dan pemahaman bacaan teks recount.

\begin{abstract}
The purpose of the research is to find out (1) The influence of Learning's Style and Vocabulary's Mastery in together toward Student's Reading of Recount Text Comprehension at SMA Negeri (Public Senior High School) in South Jakarta. (2) The influence of Learning's Style toward Student's Reading of Recount Text Comprehension at SMA Negeri (Public Senior High School) in South Jakarta. (3) The influence of Vocabulary's Mastery toward Student's Reading of Recount Text Comprehension at SMA Negeri (Public Senior High School) in South Jakarta. By sample of 72 students (Survey at SMA Negeri in South Jakarta) is the research method which used survey and with using correlation technique. Whereas the data and information in the field are netted with questioners. After that, the writer analyzed the variables of Learning's style, Vocabulary's mastery and Reading of Recount Text Comprehension: (1) There is the influence of Learning's Style and Vocabulary's Mastery in together toward Student's Reading of Recount Text Comprehension at SMA Negeri (Public Senior High School) in South Jakarta. In this case, the result is proofed by the ability of Sig's value $=0.000<0.05$ and $F_{\text {count }}=10.358$. (2) There is the influence of Learning's Style toward Student's Reading of Recount Text Comprehension at SMA Negeri (Public Senior High School) in South Jakarta. In this case, the result is proofed by the ability of Sig's value $=0.005<0.05$ and $t_{\text {count }}=2.913$. (3) There is the influence of Vocabulary's Mastery toward Student's Reading of Recount Text Comprehension at SMA Negeri (Public Senior High School) in South Jakarta. In this case, the result is proofed by the ability of Sig's value = $0.025<0.05$ and $t_{\text {count }}=2.297$.
\end{abstract}


INFERENCE: Journal of English Language Teaching

Vol. 4, No. 2, August - November 2021

p-ISSN: 2615-8671

e-ISSN: 2615-868X

Keywords: perception of learning's style, vocabulary's mastery and reading of recount text comprehension

\section{Pendahuluan}

Pendidikan pada dasarnya merupakan salah satu sarana untuk menempa diri secara esensial. Upaya untuk meningkatkan kualitas pendidikan agar diperoleh hasil belajar siswa yang optimal, maka diperlukan dukungan dan tanggung jawab semua aparat pendidikan, termasuk seorang guru. Dalam hal ini guru berfungsi sebagai pengajar yang sekaligus berfungsi sebagai pendidik. Guru sebagai seorang pendidik harus dapat mengetahui gaya belajar apa yang sesuai untuk siswa.

Pendidikan memegang peranan penting dalam menciptakan manusia-manusia berkualitas. Dalam pengajaran Bahasa Inggris, hendaknya dapat mengetahui gaya belajar siswa dalam menerima pelajaran di kelas. Dengan mengetahui gaya belajar siswa, pendidik dapat menerapkan pembelajaran yang sesuai dengan karakter siswa.

Pada dasarnya pembelajaran Bahasa Inggris merupakan proses pemahaman bahasa per kata, klausa, kalimat, paragraf sampai dengan teks. Proses ini memerlukan penguasaan kosakata yang merupakan modal dasar pemahaman Bahasa asing terutama Bahasa Inggris. Oleh karena itu, penguasaan kosakata pada siswa mempunyai kapasitas yang besar terhadap kesuksesan siswa dalam mempelajari Bahasa Inggris. Pada bagian ini guru dapat meningkatkan kemampuan pemahaman bacaan melalui pendalaman materi kosakata untuk dapat meningkatkan kemampuan siswa dalam memahami suatu bacaan.

Bahasa Inggris sebagai Bahasa Internasional yang di gunakan untuk berkomunikasi antar masyarakat dari berbagai Negara. Kemahiran menggunakan Bahasa Inggris merupakan salah satu syarat penting dalam dunia pendidikan. Di Indonesia, Bahasa Inggris merupakan bahasa asing yang di ajarkan di sekolah-sekolah. Seluruh pelajar mempelajari Bahasa ini di semua jenjang pendidikan dari sekolah dasar sampai perguruan tinggi. Karena pentingnya mempelajari Bahasa Inggris, maka belajar di setiap jenjang perlu memperhatikan beberapa aspek belajar yang sesuai agar para peserta didik memahami setiap aspek Bahasa Inggris dengan baik, yaitu aspek listening, speaking, reading dan writing.

Akan tetapi selama bertahun-tahun mempelajari Bahasa Inggris, hampir sebagian besar lulusan sekolah menengah atas bahkan sampai perguruan tinggi tidak mampu menggunakan Bahasa tersebut dalam kehidupan sehari-hari sebagai Bahasa komunikasi. Hal ini tentu tidak sesuai dengan kurikulum SMA (Garis-garis Besar Program Pengajaran Bahasa Inggris) yang menetapkan bahwa kurikulum Bahasa Inggris ini bertujuan untuk mengembalikan belajar Bahasa kepada kebermaknaan dan fungsi komunikasi tersebut.

Hasil belajar Bahasa Inggris seorang siswa di pengaruhi oleh beberapa faktor. Ada dua faktor yang berpengaruh yaitu faktor internal dan faktor eksternal. Faktor internal meliputi fisiologi yaitu kondisi fisik dan kondisi pancaindra dan juga bakat, minat, kecerdasan, motivasi dan kemampuan kognitif. Sedangkan faktor eksternal yaitu meliputi alam, sosial, dan faktor instrumen kurikulum, guru, sarana dan fasilitas serta administrasi.

Pendidikan di Indonesia masih perlu banyak perbaikan untuk mencapai hasil belajar yang optimal. Banyak faktor yang dapat menjadi sorotan untuk dijadikan sebagai latar belakang masalah guna mencapai hasil belajar Bahasa Inggris yang optimal, seperti Gaya Belajar dan Penguasaan Kosakata.

Dalam hal ini perlu diketahui berbagai macam Gaya Belajar yang telah di bahas oleh para ahli dan sepatutnya dipahami oleh para pendidik dan orang tua. Flemmings (dalam Mulyana, 2020) mengungkapkan ada empat macam Gaya Belajar yaitu: Visual, Audio, Membaca dan Kinestetik. Adapun penguasaan kosakata adalah bagian kemampuan peserta didik yang menunjang belajar Bahasa Inggris. Dengan banyaknya perbendaharaan kosakata yang dimiliki peserta didik akan mempermudah mereka dalam berkomunikasi dan menguasai Bahasa Internasional ini.

Belajar merupakan perubahan tingkah laku yang bisa diamati. Setiap orang mempunyai pengalaman dan pengetahuan dalam dirinya. Sebagai alat komunikasi yang berkembang secara terusmenerus, bahasa menuntut kesiapan pemakainya untuk menguasai kosakata dalam berbagai kegiatan berbahasa yang berguna untuk kelancaran berkomunikasi. Kosakata mempunyai pengaruh yang begitu besar bagi keberhasilan seseorang di dalam mengungkapkan gagasan atau pikirannya. Gagasan tersebut sebelum dikeluarkan menjadi sebuah kalimat ataupun ucapan yang bermakna masih berupa kumpulan- 
kumpulan kata yang kemudian dirangkai menjadi sebuah kalimat yang mempunyai makna. Maka, dalam hal ini pembahasan gaya bahasa dan penguasaan kosakata sangat erat hubungannya karena gaya belajar yang sesuai yang dapat di terapkan oleh peserta didik dan perbendaharaan kosakata yang menunjang akan mempermudah peserta didik menguasai materi belajar dan berkomunikasi dengan baik (Keraf, 2004; Tarigan, 2011; Yusliarti et al., 2020).

Oleh karena itu penulis akan membahas mengenai hubungan antara gaya belajar dan penguasaan kosakata terhadap pemahaman bacaan teks recount yang di merupakan materi ajar di sekolah menengah atas. Dalam kaitan penguasaan kosakata terhadap pemahaman teks recount sangat jelas terlihat bahwa bayaknya perbendaharaan kosakata yang para siswa kuasai atau yang mereka miliki akan sangat berpengaruh dalam memahami sebuah teks salah satunya yaitu teks recount. Mereka akan lebih cepat menangkap isi ataupun makna dari teks tersebut dengan cepat dengan kemampuan mereka menguasai kosakata dibanding dengan mereka yang tidak atau yang sedikit dalam penguasaan kosakata.

Sementara itu teks recount merupakan salah satu jenis teks Bahasa Inggris yang tujuannya adalah menceritakan ulang kejadian dimasa lampau dalam sebuah rangkaian yang terstruktur. Oleh karena itu teks recount disusun oleh sebuah orientasi, yang menandai sebuah pembukaan atau titik awal dari sebuah teks recount. Orientasi biasanya diikuti oleh rangkaian kejadian-kejadian (record of events). Dalam record of events, kejadian-kejadian dipaparkan dalam sebuah rangkaian cerita yang teratur mulai dari awal hingga terakhir. Teks recount diakhiri oleh sebuah re-orientation yang berisi kesimpulan dari penulis mengenai kejadian yang telah dipaparkan.

Upaya mengatasi kesulitan belajar bahasa dan meningkatkan mutu pendidikan sekolah telah banyak dilakukan, di antaranya adalah dengan mengenali gaya belajar siswa. Dalam interaksi belajar mengajar terdapat berbagai macam gaya belajar yang siswa terapkan sesuai dengan kemampuan mereka dan guru dapat menerapkan cara pembelajaran apa yang sesuai dapat gaya belajar siswa, hal ini bertujuan agar proses belajar mengajar dapat berjalan dengan baik. Hal ini juga bertujuan untuk menciptakan proses belajar mengajar aktif serta memungkinkan timbulnya sikap keterkaitan siswa untuk mengikuti belajar mengajar secara menyeluruh.

Keberhasilan belajar peserta didik dipengaruhi oleh faktor internal dan faktor eksternal. Faktor internal yaitu kondisi dalam proses belajar yang berasal dari dalam diri sendiri peserta didik, sehingga terjadi perubahan tingkah laku. Menurut Rohman \& Amri (Mulyana, 2020), ada beberapa hal yang termasuk faktor internal, yaitu kecerdasan, bakat (aptitude), keterampilan (kecakapan), minat, motivasi, kondisi fisik dan mental. Faktor eksternal yaitu kondisi di luar individu peserta didik yang mempengaruhi belajarnya. Dalam perilaku belajar terdapat motivasi belajar, motivasi belajar tersebut ada yang intrinsik (timbul dari dalam diri sendiri) dan ekstrinsik (dari luar individu), penguatan motivasi-motivasi belajar tersebut berada di tangan guru atau pendidik, orang tua dan anggota masyarakat lain.

Dalam penyelenggaraan pembangunan manusia yang berpendidikan, pendidikan amat diperlukan baik untuk generasi sekarang maupun generasi yang akan datang. Pembangunan memerlukan pemanfaatan semua sumber daya yang tersedia seperti sumber daya alam, modal dan sumber daya manusia. Di antara berbagai sumber daya tersebut, manusia dipandang sebagai sumber daya yang paling penting. Manusia sebagai sumber daya pembangunan yang sangat penting perlu mendapat perhatian yang serius dari pemerintah terutama pendidikan generasi muda. Ada empat kecakapan hidup yang harus dimiliki oleh seseorang yaitu :

1. Kecakapan personal (personal skill), yang mencakup kecakapan mengenal diri (self awareness) dan kecakapan berpikir rasional (thinking skill).

2. Kecakapan sosial (social skill)

3. Kecakapan akademik (academic skill), kecakapan hidup (life skill)

4. Kecakapan vokasional (vocational skill).

Secara lebih sempit, permasalahan pembelajaran dalam pelajaran Bahasa Inggris di salah satu Sekolah Menengah Atas Negeri di Jakarta Selatan, berdasarkan pengalaman peneliti sebagai guru di sebuah Sekolah Dasar Negeri dan sebagai peneliti di Sekolah Menengah Atas Negeri di Jakarta Selatan. Peneliti melihat bahwa gaya belajar pada siswa memanglah berbeda-beda berdasarkan potensi mereka masing-masing. Namun, pemahaman kosakata mereka terhadap bacaan teks recount dengan keahlian mereka sangat baik. Mereka yang menggunakan gaya belajar auditori, menguasai kosakata pada bacaan teks recount berdasar apa yang telah mereka dengar. Mereka yang menggunakan gaya belajar visual, 


\section{INFERENCE: Journal of English Language Teaching}

Vol. 4, No. 2, August - November 2021

p-ISSN: 2615-8671

e-ISSN: $2615-868 \mathrm{X}$

menguasai kosakata pada bacaan teks berdasar apa yang mereka pernah lihat atau baca. Sedangkan mereka yang menggunakan gaya belajar kinestetik, menguasai kosakata, berdasar pada pengalaman mereka dalam berinteraksi pada kegiatan pembelajaran Bahasa Inggris ataupun pada kegiatan di luar pembelajaran.

Dari ruang lingkup mata pelajaran Bahasa Inggris yang tertuang dalam Kurikulum 2013 (Alawiyah, 2015; Press workshop: Implementasi kurikulum 2013, 2014) yaitu pemerintah menetapkan agar materi ajar yang esensial, dan sesuai dengan tingkat perkembangan peserta didik. Proses pembelajaran yang terjadi di sekolah hendaknya terpusat pada peserta didik, kontekstual dan buku teks yang di pergunakan di kelas harus mengandung proses pembelajaran, sistem penilaian yang mendidik serta kompetensi yang sesuai harapan. Untuk mencapai tujuan dan target yang telah di tentukan, pengajaran Bahasa Inggris haruslah memampukan peserta didik untuk berkomunikasi dengan santun dalam komunikasi lisan dan tulisan untuk berbagai keperluan (misalnya membangun hubungan sosial dan mengembangkan wawasan melalui pertukaran informasi). Nilai kesantunan yang berlaku dalam masyarakat yang beradab merupakan landasan komunikasi yang harus dijunjung tinggi, termasuk sikap toleran, menghormati lawan bicara, kooperatif, percaya diri, kreatif, tekun, ulet dan membawa diri dengan kelembutan dan ketulusan hati.

Dari isi kurikulum 2013 di atas menyatakan bahwa, dalam pembelajaran Bahasa Inggris, siswa di harapkan menjadi pusat pembelajaran. Oleh karena itu, para siswa di harapkan mampu mengembangkan gaya belajar yang mereka kuasai dan dalam pembelajaran pun siswa berpegangan pada teks yang otentik sesuai karakter. Ini kaitan pada penguasaan kosakata dan pemahaman bacaan. Dalam hal ini, siswa dapat memupuk komunikasi yang baik dengan lawan bicara baik secara komunikasi lisan maupun tulisan.

Rendahnya pemahaman siswa dalam konsep belajar Bahasa Inggris merupakan hal yang sangat mempengaruhi keberhasilan siswa dalam menguasai Bahasa Internasional ini. Maka, diperlukanlah suatu pendekatan yang dapat mempermudah siswa dalam memahami dan menyerap pelajaran Bahasa Inggris. Dalam hal ini, pendekatan yang mendasar yang dapat menjadi indikator dalam mempermudah pelajaran yaitu dengan mengetahui gaya belajar yang diterapkan siswa dalam memahami sebuah bacaan.

Pada dasarnya tingkat keberhasilan belajar mengajar dipengaruhi banyak faktor di antaranya kemampuan guru, kemampuan dasar siswa, model pembelajaran, materi pembelajaran, sarana prasarana, motivasi, kreativitas, alat evaluasi serta lingkungan yang ke semuanya merupakan satu kesatuan yang paling berkaitan yang bekerja secara terpadu untuk tercapainya tujuan yang telah ditetapkan. Meskipun tujuan dirumuskan dengan baik, materi yang dipilih sudah tepat, jika gaya belajar yang dipergunakan kurang memadai mungkin tujuan yang diharapkan tidak tercapai dengan baik. Jadi gaya belajar merupakan salah satu komponen yang penting dan sangat menguntungkan dalam keberhasilan proses pendidikan. Menerapkan metode belajar berdasarkan gaya belajar siswa yang digunakan oleh guru diharapkan juga dapat meningkatkan aktivitas siswa di kelas dalam belajar, siswa berani menyampaikan gagasan dan menerima gagasan dari orang lain, serta kreatif dalam mencari solusi dari suatu permasalahan yang dihadapi.

Berdasarkan teori gaya belajar, guru dapat menerapkan pembelajaran yang sesuai dengan siswa. Misalnya, gaya belajar visual: alternatif strategi untuk mempermudah pengajaran pada sensor ini yaitu: menggambar, membuat catatan, menonton video, menggunakan imajinasi, demo, interaksi komputer, penggunaan kode, warna, peta pikiran, garis waktu, diagram, menghafal gambar, peta dan grafik, menggunakan kartu, menandai teks tertentu dengan warna, selain itu membuat hand out dan materi tertulis atau PowerPoint dalam bentuk semenarik mungkin dan mudah dibaca. Dapat disimpulkan dari uraian di atas bahwa orang yang mempunyai gaya pembelajar visual, menggunakan Indera mata sebagai kunci untuk memperoleh informasi, mencapai kesuksesan belajar melalui ilustrasi, membaca instruksi, mengamati gambar-gambar dan bentuk, serta meninjau kejadian secara langsung.

Selain itu, alternatif belajar yang di pakai untuk gaya belajar auditori, di antaranya alternatif strategi untuk mempermudah dan merangsang pada gaya belajar ini (Martini, 2016) yaitu: (1) Mengajak anak untuk ikut berpartisipasi dalam setiap diskusi yang dilakukan secara verbal. (2) Mendorong anak untuk membaca materi pelajaran dengan keras. (3) Menggunakan musik sebagai latar belakang untuk mengajukan anak. (4) Mengarahkan anak agar merekam materi pelajarannya ke dalam kaset/CD dan minta dia mendengarkan sebelum tidur. (5) Sebagai orang tua, baiknya bantu anak ketika belajar dengan membacakan materi pelajarannya atau mengajaknya berdiskusi mengenai materi pelajarannya. (6) Menggunakan variasi vokal (ritme, volume suara, intonasi) yang digunakan pada saat menyampaikan 
materi pelajaran. (7) Menggunakan pengulangan dengan cara meminta peserta didik mengulang kembali konsep kunci yang telah dipelajarinya. (8) Mengizinkan peserta didik untuk berbicara secara perlahan pada saat mempelajari konsep yang harus dipahaminya. (9) Mengulang penyampaian poin materi yang penting dan memberikan pertanyaan tentang hal yang sama dengan bentuk yang telah disampaikan. (10) Memberikan variasi berupa intonasi, volume maupun kecepatan terhadap materi yang disampaikan untuk lebih memberikan sensasi aural yang akan mudah dicerna.

Sedangkan untuk gaya belajar kinestesis, alternatif strategi yang dapat digunakan untuk mempermudah proses belajar peserta didik untuk gaya belajar kinestesis yaitu: (1) Tidak memaksa peserta didik belajar sampai berjam-jam. (2) Mengarahkan anak untuk belajar sambil mengekspresikan lingkungannya seperti belajar menanam dengan cara langsung mempraktikkannya. (3) Menggunakan warna terang untuk menandai hal-hal penting dalam bacaan. (4) Guru dapat membatu peserta didik dengan membuat paket-paket informasi yang berasal dari input auditorial menjadi bentuk fisik seperti membuat catatan pada kartu-kartu indeks berukuran postcard, belajar berkelompok guna memahami prinsip dan prosedur fisik, serta mengolah paket-paket informasi dalam majalah dinding kelas melalui kegiatan periksa dan baca ulang. (5) Mengizinkan peserta didik pada waktu tertentu untuk belajar sambil mendengarkan musik, sebab biasanya ketika mereka belajar dengan musik anggota tubuhnya (seperti kepala dan kaki) ikut bergerak mengikuti irama musik. (6) Menggunakan alat peraga, membuat model, aktivasi fisik, aktivasi luar kelas, drama, permainan peran diselangi istirahat. (7) Membuat kartu flash, ativasi laboratorium, wawancara, story telling ataupun drama. (8) Mendorong peserta didik agar mereka membuat catatan sendiri tentang materi yang telah di sampaikan. (9) Untuk mencapai keakraban dan menimbulkan suasana saling pengertian, guru dapat mengandalkan ucapan yang tepat sebagai kunci penting untuk menghasilkan proses belajar dan mengajar yang efektif.

Selain mengetahui gaya belajar siswa dan alternatif pembelajaran yang dilakukan di kelas. Dalam mempelajari Bahasa Inggris, diperlukan penguasaan kosakata yang setara dengan tingkat pendidikan mereka. Karena semakin tinggi tingkat pendidikan, maka siswa untuk menguasai lebih banyak lagi kosakata mereka. Dalam hal ini, diperlukan pelatihan membaca intensif dan memahami makna bacaan. Dalam pemahaman bacaan ini, siswa diminta mengetahui isi bacaan teks recount, secara langsung, siswa dapat memperdalam kosakata mereka dengan mencari kata-kata sukar atau istilah yang belum mereka tahu, ataupun sinonim dan antonim dalam teks recount. Dari masalah yang telah diuraikan di atas maka penulis akan melakukan survei untuk menganalisis pengaruh gaya belajar dan penguasaan kosakata yang dituangkan dalam tesis yang berjudul "Pengaruh Persepsi atas Gaya Belajar dan Penguasaan Kosakata terhadap Pemahaman Bacaan Teks Recount"

\section{Metode}

Untuk mencapai tujuan penelitian, penulis menggunakan metode penelitian kuantitatif. Hal ini dikarenakan dalam pengambilan, pengumpulan dan sampai memperoleh hasil datanya diperoleh dalam bentuk skor/angka. Adapun metode yang digunakan dalam penelitian ini adalah metode penelitian survei. Adapun data deskripsi penelitian gambarkan sebagai berikut: 
Tabel 1.

Deskripsi Data Penelitian Pemahaman Bacaan Teks Recount

\begin{tabular}{|l|c|c|c|}
\hline & $\begin{array}{c}\text { Persepsi atas Gaya } \\
\text { Belajar }\end{array}$ & $\begin{array}{c}\text { Penguasaan } \\
\text { Kosakata }\end{array}$ & $\begin{array}{c}\text { Pemahaman } \\
\text { Bacaan Teks } \\
\text { Recount }\end{array}$ \\
\hline $\mathrm{N} \quad$ Valid & 72 & 72 & 72 \\
Mean $\quad$ Missing & 0 & 0 & 0 \\
Median & 75.54 & 78.06 & 83.74 \\
Mode & 75.50 & 78.50 & 84.00 \\
Std. Deviation & 80 & 77 & 84 \\
Skewness & 7.051 & 6.671 & 4.186 \\
Std. Error of Skewness & -.470 & -.531 & -.679 \\
Kurtosis & .283 & .283 & .283 \\
Std. Error of Kurtosis & .236 & .302 & 1.454 \\
Range & .559 & .559 & .559 \\
Minimum & 33 & 30 & 22 \\
Maximum & 57 & 62 & 70 \\
& 90 & 92 & 92 \\
\hline
\end{tabular}

Dalam penelitian kuantitatif dengan pendekatan survei, penulis mengambil populasi Sekolah Menengah Atas Negeri (SMA) di Jakarta Selatan. Penulis memilih SMAN 38 dan SMAN 109 Jakarta Selatan. Dalam hal ini, populasi kelas 10 di dua sekolah tersebut berjumlah 502 siswa. Setelah memilih dua sekolah, penulisan, mengambil sampel untuk di jadikan bahan penelitian. Penulis mengambil sampel di kelas 10 IPS dan 10 MIPA. Sampel tersebut berjumlah 72 siswa.

Perlakuan terhadap subjek dalam penelitian ini sama yaitu berupa pemberian angket atau kuesioner mengenai gaya belajar dan penguasaan kosakata, masing-masing sebanyak 30 pertanyaan. Untuk mengetahui pemahaman bacaan teks recount, siswa di berikan pertanyaan yang terkait dengan teks recount. Tes ini berisi beberapa pertanyaan mengenai teks recount sebanyak 50 pertanyaan. Populasi terjangkau dalam penelitian ini adalah siswa kelas $\mathrm{X}$ semester 1 materi teks recount tahun pelajaran 2019/2020.

Gaya Belajar adalah merupakan kecenderungan siswa untuk mengadaptasi strategi tertentu dalam belajarnya sebagai bentuk tanggung jawabnya untuk mendapatkan satu pendekatan belajar yang sesuai dengan tuntutan belajar di kelas/ sekolah maupun tuntutan dari mata pelajaran. Sedangkan, Penguasaan kosakata adalah kecakapan seseorang dalam memahami kosakata suatu bahasa dan mampu menerapkan dalam kehidupan sehari-hari secara lisan maupun tulisan.

Gaya belajar adalah skor total yang diperoleh dari pengakuan siswa terhadap gaya belajar berdasarkan butir-butir soal pertanyaan yang tercantum pada kuesioner. Indikator dari butir-butir soal pertanyaan untuk mengukur gaya belajar sesuai dengan sikap, kemampuan dan cara siswa dalam belajar dengan menggunakan gaya belajar yang mereka sukai. Penguasaan kosakata adalah skor total yang diperoleh dari pengukuran siswa melalui pengisian angket dan kemudian di terapkan dalam tes mengenai teks recount. Indikator pengukuran butir-butir untuk penguasaan kosakata adalah mengenai pemahaman kata, makna leksikal dan pemerolehan informasi dalam bacaan.

Dalam analisis deskriptif akan dilakukan teknik penyajian data dan dalam bentuk variabel distribusi frekuensi, grafik, poligon, dan histogram untuk masing-masing kelompok data akan diolah dan dianalisis mean, median, dan modus serta ukuran simpangan seperti jangkauan variasi deskriptif digunakan SPSS versi 20.

\section{Hasil dan Pembahasan}

Seperti yang telah dijelaskan sebelumnya bahwa pada penelitian ini mempergunakan metode analisa data ANOVA dengan model deskriptif. Diperoleh hasil nilai rata-rata, nilai tertinggi dan terendah selain itu diperoleh hasil Sig yang dapat menentukan adanya pengaruh antara variabel $\mathrm{X}$ dan variabel $\mathrm{Y}$. 
INFERENCE: Journal of English Language Teaching

Vol. 4, No. 1, August - November 2021

p-ISSN: 2615-8671

e-ISSN: 2615-868X

Tabel 2. Uji Normalitas

One-Sample Kolmogorov-Smirnov Test

\begin{tabular}{|ll|l|l|l|}
\hline & & $\begin{array}{l}\text { Persepsi atas } \\
\text { Gaya Belajar }\end{array}$ & $\begin{array}{l}\text { Penguasaan } \\
\text { Kosakata }\end{array}$ & $\begin{array}{l}\text { Pemahaman } \\
\text { Bacaan Teks } \\
\text { Recount }\end{array}$ \\
\hline N & Mean & 72 & 72 & 72 \\
Normal Parameters ${ }^{\text {a,b }}$ & Std. Deviation & 7,054 & 78,06 & 83,74 \\
& Absolute &, 084 & 6,671 & 4,186 \\
Most Extreme Differences & Positive &, 055 &, 159 &, 150 \\
& Negative &,- 084 &, 090 &, 114 \\
Kolmogorov-Smirnov Z & &, 710 & 159 &,- 150 \\
Asymp. Sig. (2-tailed) & &, 695 & 1,352 & 1,274 \\
\hline
\end{tabular}

a. Test distribution is Normal.

b. Calculated from data.

Dari data di atas menunjukkan bahwa uji hipotesis yang menyatakan distribusi pada di data analisis regresi ini mengikuti distribusi normal. Hal ini di tunjukan dengan semua nilai Asymp, Sig > 0.05. Hal ini berarti semua data terdistribusi normal.

\section{Uji Multi-kolineritas}

Hasil uji multi-kolinearitas pada tabel di atas diketahui bahwa hasil Tolerance $0.884>0.1$ atau Varian Infation Factor (VIF) $1.131<10$. Sehingga dapat dinyatakan bahwa tidak ada multi-kolinearitas antara Persepsi atas Gaya Belajar dan Penguasaan Kosakata pada analisis regresi ganda ini.

Tabel 4

Hasil Perhitungan Koefisien Korelasi Ganda Variabel $X_{1}$ dan $X_{2}$ terhadap $Y$ Model Summary ${ }^{b}$

\begin{tabular}{|c|c|c|c|c|c|c|c|c|c|}
\hline Mode & $\mathrm{R}$ & \multirow{2}{*}{$\mathrm{R}$} & Adjusted R & Std. Error & \multicolumn{5}{|c|}{ Change Statistics } \\
\cline { 5 - 10 } & & Square & Square & $\begin{array}{c}\text { of the } \\
\text { Estimate }\end{array}$ & $\begin{array}{c}\text { R Square } \\
\text { Change }\end{array}$ & $\begin{array}{c}\mathrm{F} \\
\text { Change }\end{array}$ & df1 & df2 & $\begin{array}{c}\text { Sig. F } \\
\text { Change }\end{array}$ \\
\hline 1 &, $481^{\mathrm{a}}$ &, 231 &, 209 & 3,724 &, 231 & 10,358 & 2 & 69 &, 000 \\
\hline
\end{tabular}

a. Predictors: (Constant), Penguasaan Kosakata, Persepsi atas Gaya Belajar

b. Dependent Variable: Pemahaman Bacaan Teks Recount

Tabel 5

Hasil Perhitungan Pengujian Signifikansi Koefisien Regresi Variabel X1 dan X2 terhadap Y ANOVA ${ }^{\mathrm{a}}$

\begin{tabular}{|c|c|c|c|c|c|c|}
\hline & Model & Sum of Squares & df & Mean Square & F & Sig. \\
\hline \multirow{4}{*}{1} & Regression & 287,239 & 2 & 143,619 & 10,358 &, $000^{\mathrm{b}}$ \\
& Residual & 956,747 & 69 & 13,866 & & \\
& Total & 1243,986 & 71 & & & \\
\hline
\end{tabular}

a. Dependent Variable: Pemahaman Bacaan Teks Recount

b. Predictors: (Constant), Penguasaan Kosakata, Persepsi atas Gaya Belajar 


\section{Pengaruh Persepsi atas Gaya Belajar (X1) dan Penguasaan Kosakata (X2) secara bersama-sama} terhadap Pemahaman Bacaan Teks Recount

Hipotesis yang di uji:

$\mathrm{H} 0: \beta 1=\mathrm{H} 0: \beta 2=0$

$\mathrm{H} 1: \beta 1 \neq \mathrm{H} 0: \beta 2 \neq 0$

Artinya:

H0 : Tidak terdapat pengaruh persepsi gaya belajar dan penguasaan kosakata secara bersama-sama terhadap pemahaman bacaan teks recount.

H1 : Terdapat pengaruh persepsi gaya belajar dan penguasaan kosakata secara bersama-sama terhadap pemahaman bacaan teks recount.

Dari Tabel 5 dapat dinyatakan bahwa terdapat pengaruh yang signifikan persepsi atas gaya belajar terhadap pemahaman bacaan teks recount. Hal ini dibuktikan dengan pemerolehan Sig=0.00< 0.05 dan $\mathrm{FX}=10.358$. Sementara itu, persamaan garis regresi ganda dapat dinyatakan dengan $\dot{\mathrm{Y}}=56.438$ $+0.194 \mathrm{X} 1+0.162 \mathrm{X} 2$.

Hal ini memiliki pengertian bahwa kenaikan satu skor variabel persepsi atas gaya belajar dan penguasaan kosakata memberikan kontribusi sebesar 0.194 oleh X1 dan 0.162 oleh X2 terhadap variabel pemahaman bacaan teks recount. Dari tabel 4.10 juga menjelaskan bahwa secara bersama-sama variabel persepsi atas gaya belajar dan penguasaan kosakata memberikan kontribusi $5.7 \%$ terhadap variabel pemahaman bacaan teks recount.

\section{Pengaruh Persepsi atas gaya belajar (X1) terhadap pemahaman bacaan teks recount (Y)}

Hipotesis yang diuji:

$\mathrm{H} 0: \beta 1=0$

$\mathrm{H} 1: \beta 1 \neq 0$

Artinya :

$\mathrm{H} 0=$ Tidak terdapat pengaruh persepsi gaya belajar terhadap pemahaman bacaan teks recount.

$\mathrm{H} 1=$ Terdapat pengaruh persepsi gaya belajar terhadap pemahaman bacaan teks recount.

Dari Tabel 5 dapat dinyatakan bahwa terdapat pengaruh yang signifikan persepsi atas gaya belajar terhadap pemahaman bacaan teks recount. Hal ini dibuktikan dengan pemerolehan nilai Sig $=$ $0.025<0.05$ dan $\mathrm{T}=2.913$. Adapun kontribusi variabel persepsi atas gaya belajar terhadap pemahaman bacaan teks recount dapat dinyatakan dengan rumus:

$\mathrm{KD}=$ Nilai $\beta \mathrm{x} 1 \mathrm{y} \times \mathrm{x}$ Nilai Korelasi Parsialnya (rx1y) x $100 \%$

$\mathrm{KD}=0.327 \times 0.415 \times 100 \%=13.57 \%$

Dari hasil perhitungan di atas dinyatakan bahwa kontribusi persepsi atas gaya belajar terhadap pemahaman bacaan teks recount sebesar $13.57 \%$.

Pengaruh penguasaan kosakata (X2) terhadap pemahaman bacaan teks recount (Y)

Hipotesis yang diuji:

$\mathrm{H} 0: \beta 2=0$

$\mathrm{H} 1: \beta 2 \neq 0$

Artinya :

$\mathrm{H} 0=$ Tidak terdapat pengaruh penguasaan kosakata terhadap pemahaman bacaan teks recount.

$\mathrm{H} 1=$ Terdapat pengaruh penguasaan kosakata terhadap pemahaman bacaan teks recount

Dari Tabel 5 dapat dinyatakan terdapat pengaruh yang signifikan penguasaan kosakata terhadap pemahaman bacaan teks recount. Hal ini dibuktikan dengan pemerolehan nilai Sig=0.005 $<0.05$ dan $\mathrm{T}=$ 2.297. Adapun kontribusi variabel penguasaan kosakata terhadap pemahaman bacaan teks recount dapat dinyatakan dengan rumus: 
KD = Nilai $\beta$ x1y x Nilai Korelasi Pasialnya (rx1y) x 100\%

$\mathrm{KD}=0.258 \times 0.369 \times 100 \%=9.52 \%$

Dari hasil perhitungan di atas dinyatakan bahwa kontribusi penguasaan kosakata terhadap pemahaman bacaan teks recount sebesar $9.52 \%$.

Pengaruh persepsi atas gaya belajar (X1) dan penguasaan kosakata (X2) secara bersama-sama terhadap pemahaman bacaan teks recount $(Y)$

Hasil penelitian di atas menyimpulkan bahwa persepsi atas gaya belajar dan penguasaan kosakata secara bersama-sama telah memberikan pengaruh yang positif terhadap pemahaman bacaan teks recount siswa SMA Negeri di Jakarta Selatan. Hal ini mengandung arti bahwa persepsi atas gaya belajar dan penguasaan kosakata telah memberikan pengaruh yang signifikan terhadap pemahaman bacaan teks recount siswa SMA Negeri di Jakarta Selatan.

Hal ini dibuktikan dengan perolehan $\mathrm{Sig}=0.00<0.05$ dan $\mathrm{F}_{\text {hitung }}=9.286$. Sementara itu, persamaan garis regresi ganda dapat dinyatakan dengan $\hat{Y}=56.438+0.194 \mathrm{X} 1+0.162$ X2.. Hal ini menunjukkan pengertian bahwa kenaikan satu skor variabel persepsi atas gaya belajar dan penguasaan kosakata memberikan kontribusi sebesar 0.194 oleh X1 dan 0.162 oleh X2 terhadap pemahaman bacaan teks recount.

Pemahaman teks recount merupakan pengetahuan siswa dalam memahami jenis teks yang melaporkan peristiwa, kejadian atau kegiatan yang menimpa seseorang atau berupa pengalaman seseorang. Tujuan dari teks recount adalah untuk menceritakan kejadian yang terjadi pada masa yang lampau sesuai dengan urutan waktu dan strukturnya.

Persepsi belajar dalam penelitian ini merupakan kecenderungan siswa untuk mengadaptasi strategi tertentu dalam belajarnya sebagai bentuk tanggung jawabnya untuk mendapatkan satu pendekatan belajar yang sesuai dengan tuntutan belajar di kelas/ sekolah maupun tuntutan dari mata pelajaran. Sedangkan kosakata adalah rangkaian kata-kata yang terdiri dari kata tunggal, gabungan kata-kata dan idiom. Faktor inilah yang sangat penting bagi keberhasilan seseorang di dalam belajar mampu untuk berkomunikasi.

Dengan demikian dapat disimpulkan bahwa persepsi atas gaya belajar dan penguasaan kosakata mempengaruhi pemahaman bacaan teks recount siswa SMA Negeri di Jakarta Selatan. Setelah mengujinya dengan penelitian kuantitatif maka dapat di simpulkan bahwa terdapat pengaruh yang signifikan persepsi atas gaya belajar dan penguasaan kosakata secara bersama-sama terhadap pemahaman bacaan teks recount.

\section{Pengaruh Persepsi atas gaya belajar (X1) terhadap pemahaman bacaan teks recount ( $Y$ )}

Hasil penelitian ini menyimpulkan bahwa persepsi gaya belajar telah memberikan pengaruh yang positif terhadap pemahaman bacaan teks recount siswa SMA Negeri di Jakarta Selatan. Hal ini mengandung arti bahwa persepsi atas gaya belajar memberikan pengaruh yang signifikan terhadap peningkatan pemahaman bacaan teks recount siswa SMA Negeri di Jakarta Selatan.

Hal ini dibuktikan dengan perolehan $\mathrm{Si} g=0.00<0.05$ dan $\mathrm{T}_{\text {hitung }}=2.913$. Adapun kontribusi variabel persepsi atas gaya belajar terhadap pemahaman bacaan teks recount sebesar $13.575 \%$. Ini artinya persepsi atas gaya belajar para siswa memberikan kontribusi sesuai dengan tingkat kemampuannya yang cukup baik. Persepsi atas gaya belajar merupakan suatu ciri khas belajar yang di terapkan siswa dalam belajar dan menyelesaikan masalah belajarnya. Sangat beragam gaya belajar siswa ini, banyak faktornya mendorong mereka menggunakan berbagai gaya belajar yang mereka sukai, baik audio, visual, kinestetik atau berpanduan. Tidak menutup kemungkinan faktor kognitif, afektif dan psikomotor pun mempengaruhi dalam hal ini.

\section{Pengaruh penguasaan kosakata (X2) terhadap pemahaman bacaan teks recount ( $Y$ )}

Dalam hasil penelitian dan teori yang ada, dapat disimpulkan bahwa penguasaan kosakata telah memberikan pengaruh positif terhadap peningkatan pemahaman bacaan teks recount siswa SMA Negeri di Jakarta Selatan yang artinya, penguasaan kosakata yang tinggi dapat memberikan pengaruh yang signifikan terhadap peningkatan pemahaman bacaan teks recount siswa SMA Negeri di Jakarta Selatan. 


\section{INFERENCE: Journal of English Language Teaching}

Vol. 4, No. 2, August - November 2021

p-ISSN: 2615-8671

e-ISSN: 2615-868X

Hal ini dibuktikan dengan pemerolehan Sig $0.025<0.05$ dan $\mathrm{T}_{\text {hitung }}=2.297$. Adapun kontribusi variabel penguasaan kosakata terhadap pemahaman bacaan teks recount sebesar 9.52\%. Ini artinya tingkat atau level penguasaan kosakata yang dimiliki oleh para siswa memberikan kontribusi yang cukup baik terhadap pemahaman bacaan teks recount.

\section{Simpulan}

Penguasaan kosakata adalah sebuah keterampilan atau pengetahuan terhadap kata. Sedangkan pemahaman bacaan teks recount adalah pengetahuan siswa dalam memahami isi teks, struktur dan tata bahasa yang digunakan dalam teks recount. Semakin bagus penguasaan kosakata siswa maka akan semakin mudah dalam memahami isi bacaan, ide utama, ide pendukung dan kesimpulan dalam teks. Hal ini telah terbukti setelah melakukan pengujian dengan hasil yang sudah dipaparkan di atas.

\section{Daftar Pustaka}

Alawiyah, F. (2015). Kesiapan Guru dalam Implementasi Kurikulum 2013. Kajian Singkat, VI(15), 9-11. https://berkas.dpr.go.id/puslit/files/info_singkat/Info Singkat-VI-15-I-P3DI-Agustus-2014-56.pdf

Press workshop: Implementasi kurikulum 2013, Kementrian Pendidikan dan Kebudayaan Republik Indonesia (2014).

Keraf, G. (2004). Diksi dan gaya bahasa. Gramedia Pustaka Utama.

Martini, I. (2016). Pengaruh model discovery learning dengan gaya belajar VAK (Visual, Auditori, Kinestetik) terhadap pembelajaran Invertebrata di SMA. Journal of Biology Education, 5(1). http://lib.unnes.ac.id/28167/

Mulyana, A. (2020). Gaya belajar siswa, pengertian tife, dan faktor yang mempengaruhi. https://ainamulyana.blogspot.com/2015/04/gaya-belajar-siswa.html

Tarigan, H. G. (2011). Pengajaran Kosakata. Angkasa.

Yusliarti, F., Engliana, E., \& Miranti, I. (2020). Gaya bahasa aliterasi pada puisi pilihan karya Li Qing. Deiksis, 12(02), 24-31. https://doi.org/http://dx.doi.org/10.30998/deiksis.v12i01.4133 